\title{
Caring in Cancer Patient during Covid-19 Pandemic: A literature review

\author{
Nurul Huda
}

\author{
Medical Surgical Nursing Departement, Nursing Faculty, Universitas Riau, Riau, Indonesia \\ *Corresponding Email: nurulmamaifda@gmail.com
}

\author{
ARTICLE INFO \\ HOW TO CITED: \\ Huda, N. (2020). Caring in \\ Cancer Patient during Covid- \\ 19 Pandemic: A literature \\ review. Jurnal Pendidikan \\ Keperawatan Indonesia. 6(1), \\ p. $85-92$ \\ DOI: \\ 10.17509/jpki.v6i1.24635 \\ ARTICLE HISTORY: \\ Received \\ May 12, 2020 \\ Revised \\ May 21, 2020 \\ Accepted \\ June 01, 2020 \\ Published \\ June 20, 2020
}

\section{ABSTRACT}

During this Coronavirus disease-19 (Covid -19) Pandemic, the challenges for appropriate and safe delivery nursing care is becoming main concerns since cancer patients are at high risk to be infected. Oncology nurse must reassure that the patients still get the optimal treatment while in other part they have to keep their patients safe. However, the change of provision of care in order to protect cancer patients must pay more attention. The aim of this paper was to review the literature on both the impact of Covid 19 to the provision of cancer care and nursing workforce. The implications of these findings for cancer patients will also be discussed. The electronic Science direct, Googlescholar and Pubmed databases were used to identify relevant articles. A combination of keywords: cancer, care, Corona virus 19, Covid-19 and Pandemic were used to identify relevant articles. Ten articles were included in the review. The broad issues were the impact of Covid 19 on nursing delivery care and the impact to the workforce. In terms of cancer care delivery, the Oncology teams are adopting new ways to minimise the risk of Covid 19 to the patients and their staff while at the similar times they have to reassure that the patients get the optimum care. Triage patients, adjusting treatment and limitation of visitor's access to the patients is kind of changes that could do. A serious shortage and the availability of personal protective equipment are the major concern in nursing workforce changes during this pandemic. Planning or resuming cancer treatment and screening to mitigate the risk is the most important way to get the best outcomes. Hence, nurse has been pushed to adapt quickly and give their optimum nursing care to patients as well as protect themselves from cross infection

Keywords: Covid-19, cancer, nursing care

\begin{abstract}
ABSTRAK
Selama masa pandemi Coronavirus 19, tantangan terhadap pemberian asuhan keperawatan pada pasien kanker menjadi perhatian utama. Hal ini dikarenakan, pasien kanker adalah pasien dengan resiko tinggi tertular infeksi. Perawat oncology harus memastikan bahwa pasien yang mereka rawat tetap mendapatkan perawatan yang optimal walaupun disisi lain mereka harus menjaga keamanan pasien. Oleh karena itu perubahan cara layanan dalam rangka melindungi pasien harus menjadi fokus tersendiri. Tujuan dari artikel ini adalah melakukan literature review tentang impact Covid 19 terhadap layanan pasien kanker dan lingkungan kerja di unit kerja keperawatan. Aplikasi dari temuan juga didiskusikan di artikel ini. Electronic data base seperti Science Direct, Googlescholar dan Pubmed digunakan untuk mencari artikel yang berhubungan. Kombinasi dari kata kuci : cancer, care, Corona virus 19, Covid-19 and Pandemic digunakan untuk telusur artikel. 10 artikel terseleksi. Isu utama yang didapatkan adalah efek dari Covid 19 terhadap cara pemberian asuhan keperawatan dan perubahan yang terjadi dalam lingkungan tenaga kerja. Dalam hal pemberian asuhan keperawatan diketahui bahwa team oncology mengadopsi cara
\end{abstract}


baru untuk mencegah penyebaran Covid-19 kepada pasien dan staff dengan melakukan triage, menunda atau menyesuaikan treatment dan membatasi akses pengunjung ke pasien. Kekurangan tenaga kerja dan ketersediaan alat pelindung diri menjadi issue utama dalam ketenagakerjaan di area keperawatan selama masa pandemi. Merencanakan atau meresume kembali asuhan yang diberikan dan melakukan screening untuk mitigasi resiko infeksi merupakan salah satu cara yang paling naik untuk pelayanan yang terbaik. Oleh karena itu perawat harus bisa beradatasi secara cepat terhadap perubahan dan memberikan pelayanan keperawatan yang optimum dengan tidak melupakan perlindungan diri terhadap diri mereka sendiri dari infeksi silang.

Kata kunci: Covid-19, Kanker, Asuhan Keperawatan

\section{INTRODUCTION}

Cancer remains a threat across the world. It has the most devastating economic impact of any cause of death in the world and believed as the singles drain in the global economy (John \& Ross, 2010). Statistic found that cancer is still leading causes of death worldwide. In 2018, there were 18.07 million new cases and 9.8 million cancer-related deaths worldwide (Bray et al, 2018). More than a half of new cancer cases in 2018 occurred in less developed regions of the world that include Central America and parts of Africa and Asia; 65\% of cancer deaths also occurred in these regions.

At December 2019, a novel severe acute Respiratory syndrome (SARS) Coronavirus (CoV) has been identified as a agent which caused viral pneumonia (Zhu et al, 2020). Since that time, this virus has spread progressively to many countries outside China. The spread of Corona virus diseases 2019 (COVID -19) has reached the epidemiological criteria to be officially declared as a pandemic on March 2020 by World Health Organization since it has caused 118.000 cases in 114 countries and 4291 death (WHO, 2020). In Indonesia, this virus has spread to many provinces and caused death. Until first week of May 2020, Indonesia has recorded there are 13.112 cases with the total death 943 cases which made this countries in the first rank countries who have higher infected case among South east Asia countries (Worldometers, 2020).

In contrast to severe acute respiratory syndrome Coronavirus, COVID-19 has caused more mortality rate since it could make multiple organ dysfunction syndrome (Wang, 2020). For this reason, patients with cancer are in risk to be infected than individuals without cancer since they have decreased immune system due to the malignancy itself and their ongoing treatments such as chemotherapy and radiotherapy. One of the studies from Wuhan, China by Liang et al found that patient with cancer is associated with an increased risk of death and/or intensive care unit admission five times than others (OR 5.4, 95\% CI 1.8-16.2) with age, sex and comorbidities included in adjustment (Liang et al, 2020). Therefore, this patients are more susceptible of Covid 19 and have poorer prognosis providing a timely reminder that more intensive attention should be paid to patients with cancer, in case of rapid deterioration (Liang et al, 2020)

Healthcare professionals particularly nurse, who work with cancer patients should be aware of this phenomena. Full prevention must be applied during this pandemic. The change of provision of care in order to protect cancer patients must pay more attention. The aim of this paper was to review the literature on both the impact of Covid 19 to the provision of cancer care and nursing workforce. The implications of these findings for cancer patients will also be discussed. Those kind of literature review could help oncology nurse, particularly in Indonesia to consider sensitivity management approach when dealing with cancer care during this pandemic

\section{METHODS}

The electronic Science direct, Googlescholar and Pubmed, databases were used to identify relevant articles published prior to May 2020. A combination of keywords: "cancer," "care," "Covid 19," "Corona virus 19," and "Pandemic" were used to identify relevant articles. Due to the limited resources, we also included the perspective reportage. 
Aliarosa, W \& Megasari, M. | Stimulasi Critical Thingking Mahasiswa melalui Pendekatan...

Table 1. Summary of Included articles informing caring in cancer during Pandemic Covid by year of Publication and study location

\begin{tabular}{|c|c|c|c|c|c|c|}
\hline Area of research & Author & $\begin{array}{c}\text { Year of } \\
\text { publication }\end{array}$ & Language & Aim & $\begin{array}{c}\text { Study } \\
\text { location }\end{array}$ & Results \\
\hline $\begin{array}{l}\text { Lesson from the } \\
\text { Coronavirus disease } \\
\text { 2019 Pandemic: will } \\
\text { virtual patient } \\
\text { management reshape } \\
\text { uro-oncology in } \\
\text { Germany? }\end{array}$ & $\begin{array}{l}\text { Severin Rodler } \\
\text { Maria apfelbeck } \\
\text { Christian Stief } \\
\text { Volker Heinemann } \\
\text { Jozefina Casuscelli }\end{array}$ & $\begin{array}{l}2020, \text { European } \\
\text { journal of cancer }\end{array}$ & English & $\begin{array}{l}\text { To present a best } \\
\text { practice example } \\
\text { on management of } \\
\text { patients with } \\
\text { metastatic genito } \\
\text { urinary cancer } \\
\text { during Covid -19 } \\
\text { crisis } \\
\end{array}$ & Germany & $\begin{array}{l}\text { The themes were discussed in the context } \\
\text { of two broad areas: (1) Covid-19 outbreak } \\
\text { in a specialised outpatient uro-oncology } \\
\text { clinic (2) reaction to outbreak (3) follow } \\
\text { up treatment surveillance and therapy } \\
\text { decision during the Covid-19 pandemic } \\
\text { and (4) systemic treatment for preventing } \\
\text { the virus outbreak }\end{array}$ \\
\hline $\begin{array}{l}\text { Home care for cancer } \\
\text { patients during Covid- } \\
19 \text { Pandemic : the } \\
\text { double triage protocol }\end{array}$ & $\begin{array}{l}\text { Giamperrio Porzio } \\
\text { Alesio Cortelli } \\
\text { Eduardo Bruera } \\
\text { Lucilla Verna } \\
\text { Giulio Rovani } \\
\text { Vlaminia Veris } \\
\text { Giuseppi Venelli } \\
\end{array}$ & $\begin{array}{l}2020 \text { Journal of } \\
\text { pain and symptom } \\
\text { management }\end{array}$ & English & $\begin{array}{l}\text { To share the } \\
\text { procedure and } \\
\text { tools that Italy has } \\
\text { started using } \\
\text { homecare services } \\
\text { during the } \\
\text { coronavirus } 2019 \\
\end{array}$ & Italy & $\begin{array}{l}\text { The themes were discussed: } \\
\text { (1) The challenge that cancer care } \\
\text { professionals care professionals have to } \\
\text { face during a pandemic quite similar to } \\
\text { those posed by natural disasters. } \\
\text { (2) Using double triage protocol for } \\
\text { identifying patients }\end{array}$ \\
\hline $\begin{array}{l}\text { Provision of cancer } \\
\text { care during the Covid- } \\
19 \text { Pandemic }\end{array}$ & $\begin{array}{l}\text { James Spicer } \\
\text { Charlotte } \\
\text { Chamberlain } \\
\text { Sophie Papa }\end{array}$ & $\begin{array}{l}\text { 2020, Nature } \\
\text { reviews }\end{array}$ & English & $\begin{array}{l}\text { To describe the } \\
\text { provision of } \\
\text { cancer care during } \\
\text { the covid-19 } \\
\text { pandemic }\end{array}$ & $\begin{array}{l}\text { United } \\
\text { Kingdom }\end{array}$ & $\begin{array}{l}\text { The themes were discussed } \\
\text { (1) Covid-19 outcomes in patients with } \\
\text { cancer } \\
\text { (2)Acute management and palliative care } \\
\text { (3) service reconfiguration during the } \\
\text { pandemic }\end{array}$ \\
\hline $\begin{array}{l}\text { Managing patients } \\
\text { with cancer during the } \\
\text { Covid-19 pandemic : } \\
\text { frontline experience } \\
\text { from Wuhan }\end{array}$ & $\begin{array}{l}\text { H Mei } \\
\text { Y Wang } \\
\text { L Tang } \\
\text { Y Hu }\end{array}$ & $\begin{array}{l}\text { 2020, The Lancet } \\
\text { Oncology }\end{array}$ & English & $\begin{array}{l}\text { To share the } \\
\text { experiences in } \\
\text { managing patients } \\
\text { with cancer during } \\
\text { Covid-19 } \\
\text { pandemic }\end{array}$ & China & $\begin{array}{l}\text { This study highlight how to manage the } \\
\text { cancer patients during Covid } 19 \\
\text { Pandemic. They also emphasized that the } \\
\text { top priority when managing hospitalised } \\
\text { patients with cancer is the control } \\
\text { nosocomial infection. To decreased the } \\
\text { risk of infection, some therapy must be } \\
\text { postponed or adjusted }\end{array}$ \\
\hline $\begin{array}{l}\text { Covid -19: Impact on } \\
\text { cancer workfoorce and } \\
\text { delivery care. }\end{array}$ & Susan Mayor & $\begin{array}{l}2020, \text { The lancet } \\
\text { Oncology }\end{array}$ & English & $\begin{array}{l}\text { To describe the } \\
\text { impact on cancer } \\
\text { workforce and } \\
\text { delivery care } \\
\text { during the Covid } \\
19 \text { Pandemic } \\
\end{array}$ & $\begin{array}{l}\text { United } \\
\text { Kingdom }\end{array}$ & $\begin{array}{l}\text { This study highlight the balancing risk of } \\
\text { coronavirus disease } 2019 \text { (Covid-19) for } \\
\text { patients with cancer and healthcare } \\
\text { workers with the continue to provide } \\
\text { effective treatment and care }\end{array}$ \\
\hline $\begin{array}{l}\text { Oncology practice } \\
\text { during the Covid-19 } \\
\text { Pandemic }\end{array}$ & $\begin{array}{l}\text { Deborah Scharg } \\
\text { Dawn L hersman } \\
\text { Ethan Basch }\end{array}$ & 2020. JAMA & English & $\begin{array}{l}\text { To describe } \\
\text { oncology practice } \\
\text { during the Covid } \\
19 \text { Pandemic }\end{array}$ & $\begin{array}{l}\text { United } \\
\text { States }\end{array}$ & $\begin{array}{l}\text { This paper highlight three points how } \\
\text { should practice in oncology area during } \\
\text { this pandemic which are (1) patients and } \\
\text { oncologist rapidly adapted to the new } \\
\text { way of communicating (2) care that } \\
\text { cannot delivered remotely has marginal } \\
\text { effect on quality of life and (3) the } \\
\text { incremental benefits of treatments with } \\
\text { higher risk become deprioritized. }\end{array}$ \\
\hline $\begin{array}{l}\text { Navigating the Covid- } \\
19 \text { Pandemic as } \\
\text { oncology nurse }\end{array}$ & Catlin Nalley & $\begin{array}{l}2020 \\
\text { ONCOLOGY } \\
\text { TIME }\end{array}$ & English & $\begin{array}{l}\text { To share the } \\
\text { opinion related to } \\
\text { navigating care as } \\
\text { oncology nurse } \\
\text { during the Covid } \\
19 \text { Pandemic }\end{array}$ & $\begin{array}{l}\text { United } \\
\text { States }\end{array}$ & $\begin{array}{l}\text { This paper emphasize how nurse should } \\
\text { navigate the patients during the Covid } 19 \\
\text { pandemic. It focuses on how nurses } \\
\text { tackling unique challenges, transmission } \\
\text { concerns and use their self as an integral } \\
\text { resource for patients and how they find } \\
\text { the support for themselves as a front line } \\
\text { healthcare }\end{array}$ \\
\hline $\begin{array}{l}\text { Cancer care during the } \\
\text { spread of coronavirus } \\
\text { disease } 2019 \text { (COVID- } \\
\text { 19) in Italy: young } \\
\text { oncologists' } \\
\text { perspective }\end{array}$ & $\begin{array}{l}\text { Matteo Lambertini } \\
\text { Angela Toss } \\
\text { Antonio Passaro } \\
\text { Carmen } \\
\text { Cristiciello }\end{array}$ & $\begin{array}{l}2020 / \text { ESMO } \\
\text { Open, BMJ }\end{array}$ & English & $\begin{array}{l}\text { To describe how } \\
\text { to care on cancer } \\
\text { during the Covid } \\
19 \text { Pandemic }\end{array}$ & Italy & $\begin{array}{l}\text { This paper emphasize practical } \\
\text { suggestion on how to implement cancer } \\
\text { care during the Covid } 19 \text { outbreak and } \\
\text { the main challenges for cancer research }\end{array}$ \\
\hline $\begin{array}{l}\text { Cancer patients in } \\
\text { SARS-CoV-2 } \\
\text { infection: a nationwide } \\
\text { analysis in China }\end{array}$ & $\begin{array}{l}\text { Wenhua Liang, } \\
\text { Weijie Guan, } \\
\text { Ruchong Chen } \\
\text { Wei Wang, Jianfu } \\
\text { Li, Ke Xu, } \\
\text { Caichen Li, Qing } \\
\text { Ai, Weixiang Lu, } \\
\text { Hengrui Liang, } \\
\text { Shiyue Li, } \\
\text { Jianxing He }\end{array}$ & $\begin{array}{l}\text { 2020/ The Lancet } \\
\text { Oncology }\end{array}$ & English & $\begin{array}{l}\text { To explore the } \\
\text { risk transmission } \\
\text { of Covid } 19 \text { on } \\
\text { cancer patient and } \\
\text { strategies to } \\
\text { manage the cancer } \\
\text { patients during } \\
\text { Covid-19 crisis }\end{array}$ & China & $\begin{array}{l}\text { This paper showed that patients with } \\
\text { cancer had poorer outcomes from } \\
\text { COVID-19. This paper also purpose } \\
\text { three strategies for managing care during } \\
\text { the Covid-19 crisis which are intentional } \\
\text { postponing of adjuvant chemotherapy or } \\
\text { elective surgery, equipped stronger } \\
\text { personal protection and doing more } \\
\text { intensive surveillance or treatment when } \\
\text { patients with cancer are infected with } \\
\text { SARS-CoV-2 }\end{array}$ \\
\hline $\begin{array}{l}\text { COVID-19: a } \\
\text { challenge for oncology } \\
\text { services, }\end{array}$ & $\begin{array}{l}\text { Bertrand Routy, } \\
\text { Lisa Derosa, } \\
\text { Laurence Zitvogel } \\
\text { \& Guido Kroemer }\end{array}$ & $\begin{array}{l}\text { 2020/OncoImmun } \\
\text { ology }\end{array}$ & English & $\begin{array}{l}\text { To describe } \\
\text { challenges in } \\
\text { oncology services } \\
\text { during the Covid- } \\
19 \text { Pandemic }\end{array}$ & Canada & $\begin{array}{l}\text { This paper highlight the challenging for } \\
\text { oncology services in terms of outpatient } \\
\text { management, inpatients management, } \\
\text { clinical trials and unmet research meets. }\end{array}$ \\
\hline
\end{tabular}




\section{Inclusion and Exclusion criteria}

This review aimed to provide an overview of covid 19 impact to the provision of cancer care and the nursing workforce. A comphrehensive and through review was conducted to search by using academic data base. The search period ran from january 2020 to May 2020. The paper which included in this review must be related to oncology care challenges during Covid 19 Pandemic. Due to limited resources, Reportage, view point and case study were also included to enable a comphrehensive description of oncology care during this Covid-19 crisis in the world. We limited the search to english language articles. Each of article identified must read in full and assessed for its relevance. We exlcuded the article which could not be read in full accessed and from the grey literature such as the website.

\section{RESULT}

This review identified ten articles that met the inclusion criteria. Most papers discussed the oncology practice during the Covid 19 Pandemic. Of these, a half of study were conducted in Europe (50\%) followed by United states (20\%), China (20 $\%)$ and Canada (10\%). Most of paper were describing the oncology care challenges in healthcare services and only one paper particulalrly focus on the role of oncology nurse ( see table 1). The broad issues were the impact of Covid 19 on nursing delivery care and the impact to the workforce. The paragraph below will be explained both of those issue and discussed how oncology nurse doing navigating in caring during the pandemic of Covid 19.

\section{The impact of Covid 19 on nursing care delivery}

Covid 19 has specific symptoms such as fever, fatigue, dyspnoea and arthralgia. Those symptoms are quite similar with those cancer patients particularly for the people who is undergoing the treatments. Therefore, acknowledged the Covid 19 symptoms earlier in such as patients become little bit confusing (Spicer et al, 2020). Patients with fever or respiratory symptoms need to be triage when they arrive at cancer centre. Nurse must have a clinical skills to differentiate between the Covid 19 symptoms and the effect side symptoms regarding the received treatments. Based on the guidelines provided by National Institute for health and Care excellence (NICE) state that the differential diagnosis must includes the possibility of neutropenia sepsis (The UK National Institute of Health and Care Excellence, 2020).

For the management of outpatient with cancer, the top priority is the control of nosocomial infection. Chemotherapy unit should be Covidfree. Telephone screening of patients should be mandatory prior to receiving treatment. If the unit found that patients have some Covid symptoms, the patients should be assesed throughly. In order to reduce the contamination, patients must recieved their therapy without accampanion of their family and non urgent imaging and visiting should be postponed ( Routy et al, 2020)

In the inpatients setting, the patients who suspected Covid 19 must be separated with patients who not suspected. Furthermore, limitation of visitor's access to the patients, even for close family must be considered. This consideration will be a policy to prevent the virus spreading out. This also due to the limitation supply of personal protective equipment in the hospital setting (Spicer et al, 2020). Unfortunately, this policy could lead the psychological problem to the patients since they feel less of support system which could lead them to have suboptimal care and symptoms management.

Since their treatment of primary diseases could not discontinued, patients with cancer is regarded as a special group during this Covid 19 Pandemic. More attention must be given for this group. However, to reduce the risk of infection some of their treatments must be postponed such as post-operative chemotherapy. Patients who got concurrent chemotherapy or radiotherapy could postpone their therapy and for another special risk patients such as elderly, the chemotherapy protocol should be adjusted (Mei et al, 2020). For patients receiving adjuvant therapy for curable cancers, delaying initiating or abbreviating the number of 
cycle is a kind of an optional way (Schrag, 2020). Study case report from Wuhan China found that patients with blood cancer were more predisposed to Covid 19 infection compared to the solid tumour. Those could be caused by receiving aggressive chemotherapy protocols which lead them to impaired immunity and put them in higher risk of infection. Furthermore chemotherapy-free alternatives involving oral or targeted drugs which do not require hospital administration could be an alternatives way to prevent the infection and protect the patients (Mei et al, 2020). However, it should be recognised that an evidence-based estimation of the impact of treatment delay or interruption on the risk/benefit balance for each individual patient is currently lacking. Therefore, oncologists must consider on a case-by-case basis and the possibility of a delay in treatment administration (Lambertini et al, 2020).

However, some of cancer treatment that has potential to cure and cannot safely delayed could not be modified such as patients with new diagnoses of acute leukaemia, high grade lymphoma and those with chemotherapyresponsive tumour such as testicular cancer. The delayed treatmet or modified treatmet will increase the mortality. If we tried to delayed the treatments, those kinds of cancers are seems more lethal than Covid 19 (Schrag, 2020). As oncology nurse, ensuring communication related to this condition is very essentials. Nurse must have conversation and documented it well. Nurse also have to make sure that patients understand that their cancer is treated appropriately and all the efforts is also to keep them safe.

Social distancing and lock down are the major issues for oncology care during this pandemic. Oncology teams are adopting new ways to minimise the risk of Covid 19 to the patients and their staff while at the similar times they have to reassure that the patients get the optimum care. The benefits of attending hospitals must be outweighed of its risk. Switching outpatient's consultation and discussions with other health professional to online or phone rather than face to face is being adopted. Remote review by telephone or phone call or video link could be used in routine practice (Mayor,2020; Spicer et al, 2020). A study case from China found that telemedicine has important role for diagnosis. They use on line clinic services which cover video consultation, text picture counselling and medicine delivery. Patients with newly diagnosed cancer should use the internet or telephone services to contact their medical staff before deciding come directly to hospital. Those action successfully decreased the attendance of patients in hospital (Wang et al, 2020). However, nurse must reassure that patients and their family have good collaboration with their healthcare team to achieve maximum outcomes. They must be thought that their compliance is very important to get the best outcomes.

The Covid 19 has also impacted to the home care delivery in cancer care. One study from Italy teach us that doing the double triage protocol could protect and decreased the risk of infection of Covid 19 to patients and healthcare and proved that a good level's acceptability. This double triage protocol has an aim to ensure the continuity care and protect the health care professionals from the infection. The first triage is a telephonic interview dedicated by professional nurse which assess the patients and their family whether they have Covid 19 symptoms. This survey do one day before the visiting time. When patients get the negative results for the first questionnaires, they will be reassessed again and they will be classified into three colour-based priority categories which are red (severe symptoms), yellow (moderate symptoms) and green (mild symptoms). Home visits are then scheduled based on those categories (Porzio et al, 2020). For each home visit, every health care provider must wear the personal protective equipment appropriately. Those kind of action has proven to reduce the virus spreading out among patients and healthcare.

\section{The impact of Covid 19 to to the workforce}

Infrastructure and staffing levels in cancers services are affected by Covid 19. Some of countries has policy to restrict on access to operating theatres and anaesthetic which has led to 
substantial problems for cancer patients who need surgery and brachytherapy (National Health Services, 2020). Therefore, healthcare team must be selected the patients based on priorities. This could make some difficulties to ensure that those cancer patients has received appropriate care when the resources are limited. Prioritizing must also include the balance of benefits treatments against the risk. Every efforts should be made to avoid the compromising the delivery evidence based of cancer care when infection risk are outweighed by the benefits treatments (Spicer et al, 2019).

High rates of sickness among health worker due to Covid 19 are reducing the numbers of available staff. A survey from United Kingdom found that almost $20 \%$ of health workers who fill the online surveys is taking off the works (National Health Service, 2020). They have to isolate them self since they are suspected of Covid 19 diagnosis. Consequently, Hospital will suffer from serious shortage of health care staff. Furthermore, their absences would also have directly an impact to the care delivery services and staffing (Mayor, 2020).

The Covid 19 Pandemic also impact the availability of personal protective equipment. It is important to equip the health care provider with the appropriate protective equipment, screen the patients earlier and minimise the face to face contact if possible. However, during the pandemic healthcare provider use more personal protective equipment than before. This has led the growing concern of oncology nurse who administer chemotherapy and raising the question who will get the priority. This becomes the initial concern for the oncology nurse (Nalley, 2020) Therefore, modification of delivery care is important to protect the patients and health care provider and keeping the availability to the personal protective equipment is still the big issue.

\section{DISCUSSION}

The Covid 19 has big impact to health care delivery system not only in the delivery care but also the workforce area. We are facing the unique challenges since we have to balance between providing live-saving cancer care and mitigating the risk of Covid 19. The care of delivery has also modified and changed to save life and transcend the new physical barriers. As non-essentials surgery would be postponed and some facilities is limited, the way they delivery of care has shifted to online, telephone or telemedicine. Those virtual tools allow oncology nurse to reduce the risk of Covid 19 exposure. The use of telemedicine also push nurse to adjust their care with different approach particularly their privacy (Nalley, 2020). When nurse have a phone call with the patients, they have to make sure that their conversation is not heard by others. Furthermore, using telemedicine also make nurse to have more ability to transfer their skill to patients and continuing educated the patients since the nurse are their excellence resources. Nurse must direct the patients to receive appropriate sources of information as well as quickly adapt the changes of environment.

The shortage of clinical staff during this pandemic is also made some problems in nursing workforce. However, there are some common sense guidelines that must be emphasized. The hospital should not across-assign nurses to unit caring for Covid 19 with unit caring for cancer patients. This kind of transmission is the main concerns among cancer care area (Nalley, 2020; Routy, 2020).

The limitation of accessibility for visitors in hospital also has many consequences. Although this policy is believed to the best way in reducing cross infection, this also has negative influences especially for psychological condition of patients. Nurse must keep their patients mental health still stabile and keep them contact with the family by using video call and telephone calls but in the meantime nurse must be there with the patients. This limitation also influences the nurse workload since they also do their administrative task as well as accompany the patients in a room to make them comfort, listening and supporting them in order to reduce their psychological distress.

The Covid 19 has many impact to the delivery and workforce of cancer care area. Planning or resuming cancer treatment and screening to mitigate the risk is the most important way However, nurses played important and central 
role in the provision of cancer care. The changes of the way how to delivery cancer care has pushed nurse to adapt quickly and give optimum nursing care to their patients. Besides that, they have to protect themselves from cross infection. Cancer diagnosed are tremendous attached to patients. In this during pandemic, nurse must reassure that the patients still get the optimal treatment while in other part they have to keep their patients safe. Thus, the health care providers especially nurse should always being with patients, listening them, make sure that they are comfort. Furthermore, nurse must keep their communication is clear and their patients understanding what they mean and follow their guidelines. Those all the things could improve optimum outcomes and compliance.

However, this study has some limitation. First, this study was no explicit critical appraisal since this study was a comprehensive review of the literature. The decision is not to use systematic review is based on the purpose of this study which only explorative rather than seeking answer to a specific clinical question and due to the limited resources. Another limitation is some of studies

\section{REFERENCES}

Routy. B., Derosa L., Zitvogel L., \& Guido Kroemer (2020). COVID-19: a challenge for oncology services, OncoImmunology, 9:1, 1760686, DOI: 10.1080/2162402X.2020. 1760686 To link to this article: https://doi.org/10.1080/2162402X.2020.1760 686

Bray, F., Ferlay, J., Soerjomataram, I., Siegel, R. L., Torre, L. A., \& Jemal, A. (2018). Global cancer statistics 2018: GLOBOCAN estimates of incidence and mortality worldwide for 36 cancers in 185 countries. CA: A Cancer Journal for Clinicians, 68(6), 394-424. doi:10.3322/caac. 21492

Hanna, T.P., Evans, G.A. \& Booth, C.M. Cancer, COVID-19 and the precautionary principle: prioritizing treatment during a global pandemic. Nat Rev Clin Oncol 17, 268-270 (2020). https://doi.org/10.1038/s41571-0200362-6 using reportage reports which has not proven its realibility and validity. The third limitation, all of studies comes from developed countries which have excellence health facilities and health care system. So, it could not be generalized to the other countries whose facilities is limited. Particularly this study was only too acknowledged and explored the impact of Covid 19 pandemic to the delivery of cancer care.

\section{CONCLUSION}

Covid 19 has brought the challenges to health care professionals. This present study indicated that Pandemic of Covid 19 has impacted on nursing care delivery and their workforce environment. Some policy has issued to prevent the virus spreading out among patients, family and health care professionals. Modification of delivery care is important to protect the patients and health care provide. In addition, healthcare professional must also be aware for this issues and adopt the changes quickly. Thus, nurse can lead appropriate nursing intervention for every patients and establish the safe environment during this pandemic.

John, R. \& Ross, H. (2010). The Global Economic Cost of Cancer. American Cancer Society and Livestrong. Retrieved from http://www. cancer.org/acs/groups/content/@international affairs/documents/documentacspc-026203.pdf

Lambertini M, Toss A, Passaro A, et al (2020). Cancer care during the spread of coronavirus disease 2019 (COVID-19) in Italy: young oncologists' perspective. ESMO Open2020;5: e000759. doi:10.1136/esmoopen-2020-000759.

Mayor S (2020). Covid 19 : Impact on cancer workforce and delivery of care Lancet News. Vol 21, issue 5, p633.DOI:https://doi.org/ 10.1016/S1470-2045(20)30240-0 Retrieved from https://www.thelancet.com/journals/ lanonc/article/PIIS1470-2045(20)30240-0/ fulltext.

Mei, H., Dong, X., Wang, Y., Tang, L., \& Hu, Y. (2020). Managing patients with cancer during the COVID-19 pandemic: frontline experience from Wuhan. The Lancet 
Oncology, 21(5), 634-636. doi:https://doi.org/ 10.1016/S1470-2045(20)30238-2.

Nalley C (2020). Navigating the COVID-19 Pandemic as an Oncology Nurse, Oncology Times: Volume 42 - Issue 8 - p 11,18 doi: 10.1097/01.COT.0000661864.55789.d7.

National Health Service (2020) Survey on NHS physician work absence during COVID-19 pandemic. Retrieved from https://www. rcplondon.ac.uk/news/covid-19-and-itsimpactnhs-workforce accessed, May, 2020.

NHS England (2020). Clinical guide for the management of non-coronavirus patients requiring acute treatment. Retrieved from https://www.england.nhs.uk/coronavirus/wpcontent/uploads/sites/52/2020/03/specialtyguide-acute-treatment-cancer-23-march2020.pdf accessed at May, 11, 2020.

Porzio, G., Cortellini, A., Bruera, E., Verna, L., Ravoni, G., Peris, F., \& Spinelli, G. (2020). Home Care for Cancer Patients During COVID-19 Pandemic: The Double Triage Protocol. Journal of pain and symptom management, S0885-3924(20)30172-X. Advance online publication. https://doi.org/ 10.1016/j.jpainsymman.2020.03.021

Rodler, S., Apfelbeck, M., Stief, C., Heinemann, V., \& Casuscelli, J. (2020). Lessons from the coronavirus disease 2019 pandemic: Will virtual patient management reshape uro- oncology in Germany? European journal of cancer. Vol 132, 136-140. Advance online publication. https://doi.org/10.1016/j.ejca. 2020.04.003.

Schrag, D., Hershman, D. L., \& Basch, E. (2020). Oncology Practice During the COVID-19 Pandemic. JAMA. doi:10.1001/jama.2020. 6236.

Spicer, J., Chamberlain, C. \& Papa, S (2020). Provision of cancer care during the COVID19 pandemic. Nat Rev Clin Oncol. https://doi.org/10.1038/s41571-020-0370-6

W. Liang, W. Guan, R. Chen, W. Wang, J. Li, K. $\mathrm{Xu}$, et al (2020). Cancer patients in SARSCoV-2 infection: a nationwide analysis in China Lancet Oncol, 21 (3), pp. 335337, 10.1016/S1470-2045(20)30096

Wang C, Horby PW, Hayden FG, Gao GF (2020). A novel coronavirus outbreak of global health concern. Lancet; published online Jan 24. https://doi. org/10.1016/S0140-6736(20)30185-9

Worldometers (2020). Update Coronavirus Indonesia. Retrieved from https://www. worldometers.info/coronavirus////country/ind onesia/ accessed May,2020.

Zhu et al (2020) Zhu N, Zhang D, Wang W, et al. A novel coronavirus from patients with pneumonia in China, 2019. $N$ Engl J Med 2020;382:727-33. 